\title{
John Pym and Libellous Politics in Early Civil War England
}

\author{
Samuel Fullerton \\ Department of History, Vanderbilt University, Nashville, TN, USA \\ Email: Samuel.c.fullerton@vanderbilt.edu
}

\begin{abstract}
This article explores the royalist libels that afflicted the parliamentarian leader John Pym during the early 1640 s to argue that the period marked an important turning point in English libellous politics. First, like many of the political libels circulating in early Civil War England, royalist attacks against Pym transitioned unsteadily from manuscript to cheap print and then finally into official court-sponsored publications throughout the period as contemporaries grew more comfortable with openly libellous language. That medial transformation, in turn, was informed by a broader personalization of politics that drew on early Stuart modes of 'politic thinking' to frame the nascent military conflict as a battle of rival political personalities. Both contexts informed the creation and dissemination of the most vicious anti-Pym libel of the period: an allegation that Pym's mother had once committed the act of bestiality with a horse, and that Pym himself was the miscegenated result of their illicit union. Rather than a spurious invention, moreover, the horse libel in fact possessed tangible roots in an embarrassing episode of Pym's family history thirty years prior. Consequently, it demonstrates the importance of oral and scribal transmission alike in shaping and sustaining the vitriolic libellous politics of early Civil War England.
\end{abstract}

John Pym was not happy in March 1643. Weeks earlier, an anonymous pamphleteer had accused the parliamentarian luminary of countenancing 'Prophanenesse, murther, [and] disloyalty in the highest kind' in addition to other unnamed 'filthinesse'. Although a sympathetic defender published a riposte to these 'Diabolicall forgeries' on Pym's behalf, it was not enough for the wounded parliament-man. Soon thereafter, Pym produced his own rebuttal to the 'desperate and fame-wounding aspersions' recently directed against him by King Charles I's polemicists. In it, Pym denied having 'fomented the differences and schismes now abounding in the English Church' and balked at 'that mountaine of scandalous reports that have been inflicted on my integritie to

(C) The Author(s), 2021. Published by Cambridge University Press. This is an Open Access article, distributed under the terms of the Creative Commons Attribution licence (http://creativecommons.org/licenses/by/4.0), which permits unrestricted re-use, distribution and reproduction, provided the original article is properly cited. 
his Sacred Majestie'. ${ }^{1}$ Yet while he addressed some of those slanders directly and alluded to others in passing, Pym left unmentioned perhaps the most scandalous royalist attack of them all: a scabrous allegation that he was the bestial offspring of a sexual encounter between his mother and a horse. As the beleaguered parliament-man knew, this was no idle invention; instead, the story possessed concrete, if distorted, roots in an embarrassingly true episode of Pym family history more than thirty years prior. No wonder, then, that he kept silent. It was, in its own strange way, a true story - and that made it all the more dangerous.

The horse joke against Pym's mother represented a particularly vicious specimen of an otherwise routine contemporary phenomenon known colloquially as a 'libel': a public, textual ad hominem attack intended to undermine an enemy's personal reputation and, therefore, their political standing. Such attacks are familiar territory for scholars of seventeenth-century England. Political historians have argued that libels offer evidence of widespread popular political engagement, ${ }^{2}$ while literary scholars have examined them as a sophisticated mode of political counsel. ${ }^{3}$ Scholars of censorship and civility have also contributed to this burgeoning historiography, ${ }^{4}$ and social historians have productively contrasted political libels with other forms of oral and written defamation. ${ }^{5}$ Finally, legal scholars have offered juridical genealogies of

\footnotetext{
${ }^{1}$ A letter written out of the country to Mr Iohn Pym, E.89[5] (Oxford, 1643), p. 2; Answer to a letter written out of the country, E.246[24] (1643), sig. Av; John Pym, A declaration and vindication, E.91[34] (1643), pp. 3-4, 6. The place of publication for works published before 1800 is London unless stated otherwise.

${ }^{2}$ Richard Cust, 'News and politics in early seventeenth-century England', Past \& Present, 112 (1986), pp. 60-90; Pauline Croft, 'Libels, popular literacy and public opinion in early modern England', Historical Research, 68 (1995), pp. 266-85; Alastair Bellany, “'Raylinge rymes and vaunting verse": libellous politics in early Stuart England, 1603-1628', in Kevin Sharpe and Peter Lake, eds., Culture and politics in early Stuart England (Stanford, CA, 1993), pp. 285-310; idem, The politics of court scandal in early modern England: news culture and the Overbury affair, 1603-1660 (Cambridge, 2002); Thomas Cogswell, 'Underground verse and the transformation of early Stuart political culture', in Susan D. Amussen and Mark Kishlansky, eds., Political culture and cultural politics in early modern England (Manchester, 1995), pp. 277-300; John Walter, "'The pooremans joy and the gentlemans plague": a Lincolnshire libel and the politics of sedition in early modern England', Past \& Present, 203 (2009), pp. 29-67; Noah Millstone, Manuscript circulation and the invention of politics in early Stuart England (Cambridge, 2016).

${ }^{3}$ Andrew McRae, 'The literary culture of early Stuart libeling', Modern Philology, 97 (2000), pp. 364-92; David Colclough, 'Freedom of speech, libel and the law in early Stuart England', in Erica Sheen and Lorna Hutson, eds., Literature, politics and law in Renaissance England (Basingstoke, 2005), pp. 170-88; Joshua Eckhardt, "Love-song weeds, and satyrique thornes": anti-courtly love poetry and Somerset libels', Huntington Library Quarterly, 69 (2006), pp. 47-66.

${ }^{4}$ Annabel Patterson, Censorship and interpretation: the conditions of writing and reading in early modern England (Madison, WI, 1984); Cyndia Susan Clegg, Press censorship in Elizabethan England (Cambridge, 1997); M. Lindsay Kaplan, The culture of slander in early modern England (Cambridge, 1997); Debora Shuger, Censorship and cultural sensibility: the regulation of language in Tudor-Stuart England (Philadelphia, PA, 2006).

${ }^{5} \mathrm{~J}$. A. Sharpe, Defamation and sexual slander in early modern England: the church courts at York (York, 1980); Adam Fox, 'Ballads, libels and popular ridicule in Jacobean England', Past \& Present, 145 (1994), pp. 47-83; Laura Gowing, Domestic dangers: women, words, and sex in early modern London
} 
early modern libel laws, adding yet another layer to this robust scholarly canon. ${ }^{6}$

Even so, historians have yet to attempt a narrative history of early modern libellous politics from the sixteenth-century Reformation to the Stuart Restoration. ${ }^{7}$ Thanks to the work of Peter Lake, Alastair Bellany, Thomas Cogswell, and Mark Knights, large portions of that story are already implicit in the historiography. ${ }^{8}$ Yet one lacuna remains: namely, the role of the English Revolution in transforming the underground scribal libels of early Stuart politics into a late seventeenthcentury print-based political culture in which, Knights writes, 'ad hominem attacks were part of everyday political life'. While scholars have occasionally identified the revolutionary period as 'an obvious watershed in the history of print libel', only rarely have they scrutinized that process directly.'

Pym's polemical travails offer one starting point for that project by illuminating two major innovations in English libellous politics during the early 1640 s. The first was medial. Royalist slanders against Pym followed a common publication trajectory from illicit manuscript verses in mid-1640 to licensed royalist print by the autumn of 1643 , proving that in at least one instance, the outbreak of Civil War propelled a substantial body of scribal libels into print for the first time in English history. The horse libel also followed this path, evolving from scribal squibs into cheap print before eventually appearing in the courtsponsored royalist newsbook Mercurius Aulicus just months before Pym's death in December 1643. However, this transition was hardly straightforward: throughout the period, for instance, royalist libellers apparently remained unwilling to print the horse joke's more obscene iterations for fear of offending sympathetic readers. Rather than revealing an irreversible transformation from manuscript to print, then, Pym's libellous history instead demonstrates how freely scribal and printed polemic intermingled during the early 1640s, as contemporaries grappled with the consequences of the 1640/1 "print explosion' for English political discourse.

But the Pym libels also reveal a more permanent transformation unfolding in early Civil War England: a comprehensive personalization of politics, rooted

(Oxford, 1996); David Cressy, Dangerous talk: scandalous, seditious, and treasonable speech in pre-modern England (Oxford, 2010).

${ }^{6}$ Philip Hamburger, 'The development of the law of seditious libel and the control of the press', Stanford Law Review, 37 (1985), pp. 661-765; J. H. Baker, An introduction to English legal history (4th edn, London, 2002), ch. 25.

${ }^{7}$ Alastair Bellany, 'Railing rhymes revisited: libels, scandals, and early Stuart politics', History Compass, 5 (2007), pp. 1136-79, at pp. 1165-7.

${ }^{8}$ Peter Lake, Bad Queen Bess?: libels, secret histories, and the politics of publicity in the reign of Queen Elizabeth I (Oxford, 2016); Bellany, “'Raylinge rymes”'; Cogswell, 'Underground verse'; Mark Knights, Representation and misrepresentation in later Stuart Britain: partisanship and political culture (Oxford, 2005).

${ }^{9}$ Mark Knights, 'How rational was the later Stuart public sphere?', in Peter Lake and Steven Pincus, eds., The politics of the public sphere in early modern England (Manchester, 2007), pp. 25267, at p. 256; Alastair Bellany, 'Libel', in Joad Raymond, ed., The Oxford history of popular print culture, I: Cheap print in Britain and Ireland to 1660 (Oxford, 2011), pp. 142-63, at p. 162. For one brilliant example, see Alastair Bellany and Thomas Cogswell, The murder of King James I (New Haven, CT, 2015). 
in the Tacitean modes of 'politic thinking' that had first emerged during James's reign, that blamed the outbreak of war on specific political leaders who were then singled out and abused by enemy apologists. ${ }^{10}$ Although libels against individual politicians were hardly new in early Stuart England, the politics of personality that blossomed after 1640 were considerably more expansive, eventually encompassing nearly every public figure active in midcentury England - including, in time, the king himself. Pym was central to this process, both as a leading solicitor of libellous attacks on the king's 'evil counsellors' and as the apparent ringleader of Charles's parliamentary opposition. In this sense, Pym's unfortunate polemical history elucidates not only the tenuous, and ultimately temporary, transition of English libellous politics from manuscript to print during the early 1640s, but also the bipartisan personalization of politics that enabled it.

Biographically, few English figures have proven as elusive as John Pym, whose personal and professional life remains 'singularly obscure' despite historians' commendable efforts. ${ }^{11}$ Even so, enough evidence remains to construct an adequate portrait which, when set alongside the rising profile of early Stuart libellous politics, provides some context for his trials during the early 1640 s.

Born to Alexander and Philippa Pym in 1584, John's early life was marred by upheaval. ${ }^{12}$ His father died shortly after his birth, leading to a protracted battle over John's wardship between his mother and uncle, William Pym, that Philippa only won after the Cornish JP Sir Anthony Rous intervened on her behalf. Philippa and Sir Anthony later married, immersing young John in the Rous family's pious puritanism. ${ }^{13}$ Pym went on to nurture his godly credentials at Oxford and the Middle Temple before assuming a post administering royal revenues in Somerset. His first parliamentary appointment came in 1621. Once there, he soon became an 'important' godly figure, but 'definitely not a leader' - an inconspicuous position that was hardly premonitory of his later ascendancy. ${ }^{14}$ Later, when Charles I's personal rule (1629-40) put a temporary stop to Pym's parliamentary career, he served as a treasurer for the godly Providence Island Company. By the later 1630s, Pym had cemented his membership among Charles's puritan opposition. ${ }^{15}$

\footnotetext{
${ }^{10}$ Lake, Bad Queen Bess?; Millstone, Manuscript circulation.

${ }^{11}$ Perez Zagorin, 'The political beliefs of John Pym to 1629', English Historical Review, 109 (1994), pp. 867-90, at p. 867. See also J. H. Hexter, The reign of King Pym (Cambridge, MA, 1941); Conrad Russell, Parliaments and English politics, 1621-1629 (Oxford, 1979); idem, 'The parliamentary career of John Pym, 1621-1629', in Unrevolutionary England, 1603-1642 (London, 1990), pp. 205-28; idem, The fall of the British monarchies, 1637-1642 (Oxford, 1991).

${ }^{12}$ This paragraph draws heavily on Conrad Russell, 'Pym, John (1584-1643)', Oxford dictionary of national biography (ODNB).

${ }^{13}$ Idem, 'The wardship of John Pym', in Unrevolutionary England, pp. 145-64; C. E. Wade, John Pym (London, 1912), pp. 15-16; J. Sears McGee, 'A "carkass" of "mere dead paper": the polemical career of Francis Rous, puritan MP', Huntington Library Quarterly, 72 (2009), pp. 347-71.

${ }^{14}$ Russell, 'Pym', ODNB.

${ }^{15}$ Wade, Pym, p. 173.
} 
Meanwhile, English libellous politics were coming of age. Since the later sixteenth century, when Elizabethan leaders first perfected the "libellous secret history' as a polemical weapon against their Catholic and hyper-puritan critics, public ad hominem attacks had grown into an increasingly common-and increasingly vilified - element of contemporary political discourse. ${ }^{16}$ Although they were largely limited to subversive manuscript and oral forms after 1600 by a combination of intermittent regime censorship, ${ }^{17}$ contemporary honour culture, ${ }^{18}$ and a pervasive emphasis on public civility, ${ }^{19}$ scabrous libels repeatedly surfaced in Jacobean manuscript culture to assail public ministers, overreaching prelates, and royal favourites alike. ${ }^{20}$ During the 1620 s in particular, amid the duke of Buckingham's political apotheosis and the alarming rise of anti-Calvinist Arminians to ecclesiastical ascendancy, those slanders took on new significance as contemporary theorists adopted a cynical mode of "politic thinking' that posited the existence of a vast popish conspiracy at court to enslave the kingdom into tyranny. That conspiratorial framework, in turn, provided additional inspiration for opposition libellers to denounce the plot's malevolent architects in vicious scribal verses. Just as Pym began cutting his teeth in parliament, therefore, the rise of politic thinking prompted a dramatic increase in the volume and scope of English libellous politics. ${ }^{21}$

Like most of his fellow parliament-men, Pym was rarely a direct target of defamatory rhetoric during the 1620s; instead, most political libels targeted a small number of courtiers and royal favourites. ${ }^{22}$ But Pym's negligible libellous profile did not prevent him from experimenting with the new styles of publicity currently springing up around parliament. ${ }^{23} \mathrm{He}$ would have paid especial attention to his colleagues' strategic application of Tacitean 'evil

${ }^{16}$ Lake, Bad Queen Bess?; Alastair Bellany, 'The embarrassment of libels: perceptions and representations of verse libelling in early Stuart England', in Lake and Pincus, eds., The politics of the public sphere, pp. 144-67.

${ }^{17}$ Joseph Black, 'The rhetoric of reaction: the Martin Marprelate tracts (1588-89), anti-Martinism, and the uses of print in early modern England', Sixteenth Century Journal, 28 (1997), pp. 707-25; Cogswell, 'Underground verse'.

${ }^{18}$ Richard Cust, 'Honour and politics in early Stuart England: the case of Beaumont v. Hastings', Past \& Present, 149 (1995), pp. 57-94; Gowing, Domestic dangers.

${ }^{19}$ Anna Bryson, From courtesy to civility: changing codes of conduct in early modern England (Oxford, 1998); Craig Muldrew, The economy of obligation: the culture of credit and social relations in early modern England (Basingstoke, 1998); Shuger, Censorship and cultural sensibility.

${ }^{20}$ Pauline Croft, 'The reputation of Robert Cecil: libels, political opinion and popular awareness in the early seventeenth century', Transactions of the Royal Historical Society, 6th series, 1 (1991), pp. 43-69; Alastair Bellany, 'A poem on the archbishop's hearse: puritanism, libel, and sedition after the Hampton Court Conference', Journal of British Studies, 34 (1995), pp. 137-64; idem, The politics of court scandal.

${ }^{21}$ Millstone, Manuscript circulation.

${ }^{22}$ But see 'The wisest king did wonder when hee spy'd' (Oiii2) and 'The warrlike king was troubled when hee spy'd' (Oiii3), both in Alastair Bellany and Andrew McRae, eds., 'Early Stuart libels: an edition of poetry from manuscript sources', Early modern literary studies text series I (2005), http://purl.oclc.org/emls/texts/libels/.

${ }^{23}$ Chris R. Kyle, Theater of state: parliament and political culture in early Stuart England (Stanford, CA, 2012). See for example Pym's scribal petition to James I: 'The humble peticion', Somerset Heritage Centre, MS DD $\backslash \mathrm{AH} / 51 / 4$. I thank Noah Millstone for sharing this document with me. 
counsellor' rhetoric, which dodged the potentially fatal mistake of personally denouncing the king by instead blaming England's troubles on a group of malignant royal advisers. ${ }^{24}$ In return, as Pym also likely noticed, the Caroline regime constructed its own counter-conspiracy in which international puritanism became the root of English political instability. ${ }^{25}$ Yet while both frameworks readily lent themselves to libellous polemic, Charles's suspicion of 'popularity' meant that the vicious anti-court slanders of Pym's fellow travellers went largely unanswered by crown apologists. Instead, the king abstained from parliaments entirely after 1629 , prompting a considerable decrease in the libellous deluge. ${ }^{26}$

Then, in 1637, multiple Anglo-Scottish wars and the rapid-fire calling of two successive parliaments sent politic thinking once again rocketing into prominence. New polemics against Charles's evil counsellors soon appeared across English manuscript culture, only to be met with equally scurrilous anti-puritan attacks on the king's parliamentarian opposition. ${ }^{27}$ Dozens of individuals, from Archbishop William Laud to the puritan martyrs Henry Burton, John Bastwick, and William Prynne, were swept up in this libellous barrage. ${ }^{28}$ As civil war loomed, moreover, manuscript libels were supplemented by a growing number of cheap, anonymized printed satires that quickly threatened to surpass even the period's widest-circulating scribal materials in scope. ${ }^{29}$ Soon thereafter, the steady breakdown of Caroline press licensing cemented libellous politics as a regular, albeit controversial, feature of polemical print, spurred onward by the bipartisan belief that a coterie of evil plotters were to blame for the kingdom's worsening troubles. ${ }^{30}$

Amid these upheavals, Pym's political dominance began. From the opening days of the April 1640 'Short Parliament', when he delivered a lauded two-hour speech, Pym became the undisputed leader of Charles's parliamentary opposition. ${ }^{31} \mathrm{He}$ soon began routinely denouncing the king's evil counsellors in

\footnotetext{
${ }^{24}$ Noah Millstone, 'Evil counsel: The propositions to bridle the impertinency of parliament and the critique of Caroline government in the late 1620s', Journal of British Studies, 50 (2011), pp. 813-39.

${ }^{25}$ Jason Peacey, 'The paranoid prelate: Archbishop Laud and the puritan plot', in Barry Coward and Julian Swann, eds., Conspiracies and conspiracy theory in early modern Europe: from the Waldensians to the French Revolution (Aldershot, 2004), pp. 113-34.

${ }^{26}$ Richard Cust, 'Charles I and popularity', in Thomas Cogswell, Richard Cust, and Peter Lake, eds., Politics, religion, and popularity in early Stuart Britain (Cambridge, 2002), pp. 235-58.

${ }^{27}$ Anthony Fletcher, The outbreak of the English Civil War (London, 1981), pp. 43-57; Tim Harris, 'Charles I and public opinion on the eve of the English Civil War', in Stephen Taylor and Grant Tapsell, eds., The nature of the English Revolution revisited (Woodbridge, 2013), pp. 1-25.

${ }^{28}$ See, for example, Helen Pierce, 'Anti-episcopacy and graphic satire in England, 1640-1645', Historical Journal, 47 (2004), pp. 809-48; Beinecke Rare Book and Manuscript Library, Yale University (BRBML), Osborn MS fb106, no. 6.

${ }^{29}$ Laura A. M. Stewart, Rethinking the Scottish Revolution: covenanted Scotland, 1637-1651 (Oxford, 2016), ch. 1; Millstone, Manuscript circulation, chs. 8-9; Cogswell, 'Underground verse'.

${ }^{30}$ Joad Raymond, The invention of the newspaper: English newsbooks, 1641-1649 (Oxford, 1996); idem, Pamphlets and pamphleteering in early modern Britain (Cambridge, 2003), ch. 5; David Como, 'Secret printing, the crisis of 1640, and the origins of Civil War radicalism', Past \& Present, 196 (2007), pp. 37-82.

${ }^{31}$ Caroline Hibbard, Charles I and the popish plot (Chapel Hill, NC, 1983), p. 149; Wade, Pym, p. 177.
} 
parliament, thereby exposing prominent royal ministers to unprecedented public ridicule from anonymous libellers. In the process, however, Pym caught the eye of Charles's own polemicists. Accordingly, from the spring of 1640, he received steadily more libellous coverage from hostile commentators, first in manuscript and then in anonymous print. As Pym's political star rose, so too did the frequency and intensity of the libels, until he effectively became the chief villain of royalist polemic. Significant milestones occurred during the spring of 1641, when many contemporaries credited Pym with the execution of Charles's leading evil counsellor, the earl of Strafford; later that autumn, when Pym seized on the burgeoning Irish Rebellion to demand unprecedented parliamentary control of the military; and in January 1642, when Pym and four colleagues - the notorious 'Five Members' - narrowly escaped arrest at Charles's hands. ${ }^{32}$ The formal outbreak of war in October 1642 cemented his status as the royalists' enemy number one. Soon enough, months after the establishment of a formal royalist press corps at Oxford early in 1643, attacks against Pym's reputation were regularly airing in the pages of court-licensed print propaganda like Mercurius Aulicus. ${ }^{33}$ Those libels persisted until his sudden death in December, when royalist writers whispered that Pym's 'most loathsome and foule carkasse' was 'loaded' with grotesque 'diseases'. ${ }^{34}$ For Charles's partisans, at least, it must have seemed a fitting end.

\section{II}

What did those libels look like? As Tim Harris notes, although Charles's official press corps largely demurred from forthrightly libellous attacks until mid- to late 1643, freelancing royalist polemicists wasted no time in 1640 and 1641 hijacking the anti-puritan language of earlier religious satirists to construct a libellous equivalence between godly hypocrisy and the nascent parliamentarian rebellion. ${ }^{35}$ Consequently, many elements of traditional English anti-puritanism - including charges of sedition, separatism, hypocrisy, and lechery - soon became trademarks of royalist libellous polemic. ${ }^{36}$ In keeping with the conspiratorial bent of early Stuart 'politic thinking', moreover, loyalist writers increasingly directed this rhetoric at specific parliamentary leaders in order to frame the rebellion as a sinister godly plot. In doing so, they often tailored their libels to reflect their targets' personal histories. For instance,

\footnotetext{
${ }^{32}$ For these events, see Russell, Fall of the British monarchies.

${ }^{33}$ P. W. Thomas, Sir John Berkenhead, 1617-1679: a royalist career in politics and polemics (Oxford, 1969); Robert Wilcher, The writing of royalism, 1628-1660 (Cambridge, 2001); Anthony Milton, Laudian and royalist polemic in seventeenth-century England: the career and writings of Peter Heylyn (Manchester, 2007).

${ }^{34}$ Aulicus, no. 49, E.79[1] (Oxford, 9 Dec. 1643), p. 703. In response, Pym's colleagues produced a printed rebuttal: A narrative of the disease and death of...John Pym, E.79[27] (1643).

${ }^{35}$ Harris, 'Charles I and public opinion'.

${ }^{36}$ Patrick Collinson, 'Antipuritanism', in John Coffey and Paul C. H. Lim, eds., The Cambridge companion to puritanism (Cambridge, 2008), pp. 19-33; Peter Lake, 'Anti-puritanism: the structure of a prejudice', in Kenneth Fincham and Peter Lake, eds., Religious politics in post-Reformation England (Woodbridge, 2006), pp. 80-97.
} 
parliament's future general, the earl of Essex, was derided as an effeminate cuckold as royalists recalled his embarrassing divorce during the Overbury affair of 1613-14, while the leading parliament-man Sir Henry Vane was mocked as an unhinged godly radical in light of his controversial stint as governor of Massachusetts Bay during the outbreak of the Antinomian Controversy. ${ }^{37}$ Pym, well known for his godly fervour, received the same anti-puritan treatment, although it did not always prove uniformly effective.

Most of the Pym libels followed a relatively consistent publication trajectory from subversive manuscripts into formal royalist print between 1640 and 1643, supplemented by a vibrant culture of oral slander that denigrated Pym and his colleagues as 'traytors to their kinge'. ${ }^{38}$ Throughout, royalist libellers largely focused on Pym's presumed role as Charles's chief opponent in Westminster. This characterization, which in many ways accurately reflected Pym's ballooning profile, grew more pronounced throughout the period. During early to mid-1642, for example, Pym was frequently ridiculed as one of the infamous Five Members who fled from royal arrest in January. ${ }^{39}$ Increasingly, however, scribal writers described the war as a personal conflict between Pym and Charles. Many royalists accused Pym of aspiring to the crown himself, and he quickly earned a treasonous moniker, 'King Pym', that reflected his alleged royal ambitions. 'Is there noe Kinge, but Pym', asked one commentator in verse, while a different scribal satirist rhymed, 'change places Charles, \& put on Pym's grave gowne / Whilst in the upp[er] house he weares the Crowne'. ${ }^{40}$ Still others wondered if 'King Pime' would flee to New England after his coalition's impending defeat. ${ }^{41}$ It did not take long for the nickname to stick.

Meanwhile, royalist scribal satirists also slandered Pym as a puritan zealot. From mid-1641, hostile critics had regularly portrayed the parliamentary rebellion as a godly conspiracy against the English church, and Pym was quickly identified as one of its chief masterminds. Royalists were not too far off the mark with these allegations: there was certainly truth to the claim that Pym's religious principles drove his political opposition, even if some of his colleagues were far more radical. ${ }^{42}$ Several scribal verses commented on Pym's 'zeale' and compared it with that of '[Lord] Brooke' and '[Viscount] Say [and Sele]', two other leading godly parliamentarians. One of these poems, later printed at Oxford, stridently denounced Pym and others who

\footnotetext{
${ }^{37}$ On Essex, see for example The Henry E. Huntington Library, San Marino, CA (HEHL), EL 8883a; The Cambridge royallist imprisoned, E.62[15] ([Oxford?], 1643), sig. A3r. On Vane, see for example Aulicus, no. 27, E.60[18] (Oxford, 9 July 1643), p. 348; Bodleian Library, Oxford University (Bod.), MS Ashmole 36-7, fo. 67v.

${ }^{38}$ London Metropolitan Archives, MJ/SR/927/7.

${ }^{39}$ HEHL, HM 16522, p. 13.

${ }^{40}$ HEHL, EL 8807; Bod., MS Ashmole 36-7, fo. 73r. See also ibid., fo. 92r; Cambridge University Library, MS Baker Mm.1.46, p. 101; HEHL, HM 16522, p. 142; Bod., MS Ashmole 47, fo. 132r; Russell, Fall of the British monarchies, p. 404; Michael Braddick, God's fury, England's fire: a new history of the English Civil Wars (London, 2008), pp. 204-5.

${ }^{41}$ HEHL, EL 8889.

${ }^{42}$ Russell, 'Pym', ODNB; McGee, 'A “carkass”'; Hibbard, Popish plot.
} 
'boldly preach blasphemy \& sedition, / and pray high treason by the houre'.43 For these writers, 'reforminge Pim' numbered among the chief sectarian 'Brownists' allegedly responsible for the godly plot. ${ }^{44}$ As the Long Parliament pursued increasingly radical religious reforms during the spring and summer of 1641 , moreover, they appeared to be making considerable headway.

Several other themes informed the scribal Pym libels of 1640-2. Among them were Pym's role in crafting parliament's rapacious wartime taxation schemes as well as his abilities as a forger. ${ }^{45}$ Again, these tropes loosely reflected reality: Pym really did have a hand in writing much early parliamentary economic legislation, while in 1642 a sharp-eyed Oxfordshire observer correctly identified Pym's hand behind an anonymous printed attack on the royalist press corps. ${ }^{46}$ But these were minor elements of the royalists' libellous barrage, which continued to highlight Pym's political and religious deviance above all else.

In keeping with another prevailing trope of anti-puritan satire, some royalists also linked Pym's godly religion with an unnatural sexual appetite. However, unlike royalist jabs at his political and religious leanings, such attacks had slim factual backing. Pym was a widower by April 1640, and no extant evidence suggests that he engaged in illicit sexual activity either before or after his wife's demise. ${ }^{47}$ The implausibility of these charges probably explains their rarity: they were simply too unbelievable to carry much weight with readers. Nevertheless, royalists' pervasive reliance on anti-puritan sexual slander ensured that Pym was libelled intermittently throughout the early 1640 s as a stereotypical godly lecher. One parodic poem noted that 'faire weomen' could 'prevaile with $\mathrm{P}[\mathrm{ym}]$ / if from thy Brest one sigh shall come', suggesting the parliament-man's weakness for female attention. Another verse portrayed him winkingly as 'a Zealous man \& a true brother' that the lascivious puritan 'holy sisters' were known to sexually 'approve of like 'none other. ${ }^{48}$ Again, neither accusation appears to have contained even a scrap of truth, although they may well have reflected more localized allegations of personal unchastity circulating in manuscript or oral forms. More likely, however, they represent standard royalist libellous tropes that failed to gain serious traction precisely because they were so difficult to swallow.

These scribal libels slowly transitioned into print alongside Pym's rise to parliamentary ascendancy during mid- to late 1642. By the following winter, when Charles established his headquarters in Oxford, print had overtaken manuscript as England's primary libellous medium. Thereafter, royalists

${ }^{43}$ HEHL, EL 8848; Bod., MS Rawl. Poet. 62, fo. 46r. For the printed version, see The humble petition of the House of Commons, E.69[24] (1643), pp. 7-8.

${ }^{44}$ Bod., MS Rawl. Poet. 71, p. 124; British Library (BL), Sloane MS 1467, fo. 130 r.

${ }^{45}$ For the former, see Bod., MS Ashmole 36-7, fo. 5r; HEHL, EL 8882; BRBML, Osborn MS b101, pp. 128-9; Aulicus, no. 43, E.75[13] (Oxford, 28 Oct. 1643), p. 604. For the latter, see The complaint of the kingdome, Wing C5616 ([Oxford], 1643), p. 15; Aulicus, no. 44, E.75[37] (Oxford, 4 Nov. 1643), p. 630; ibid., no. 48, E.78[16] (Oxford, 2 Dec. 1643), p. 687; A letter written out of the country, p. 5.

${ }^{46}$ Bod., MS Top. Oxon. C. 378, pp. 342-3.

${ }^{47}$ Russell, 'Pym', ODNB.

${ }^{48}$ BL, Harley MS 6918, fo. 94r; HEHL, EL 8841. 
generally deployed pamphlets rather than scribbled separates to condemn Pym for having 'belch'd out most horrid treasons against Gods Anointed [i.e. Charles]' and his royal consort. ${ }^{49}$ Eventually, even official royalist productions like Aulicus joined the libellous chorus. ${ }^{50}$ The King Pym trope remained popular during this transition, although formal Oxford publications usually avoided it: for example, while one September issue of Aulicus sneered that 'to scandalize the sacred person of Mr Pym' was 'a crime no lesse then Treason now in London', it did not attach the faux-royal epithet, perhaps for fear of offending the king. Even so, freelancing royalist writers unreservedly decried parliamentarians who 'fight for the King but...meane for king Pim'. In this vein, Pym's seditious politics remained a dominant focus of royalist print throughout $1643 .^{51}$

Attacks on Pym's religion also soon surfaced in print. One anonymous printed satire accused the parliament-man in February of "bribery from Papists, separating of Protestants, countenancing of Anabaptists, and all other Sectaries, [and] inhibiting good Preachers,.$^{52}$ In July, another royalist pamphlet described Pym as 'the grand father of all the purer sort' currently plotting 'to overthrow the Church and State, [and] to make them as Sodome', while a different tract published after Pym's death numbered him among the devil's own 'sons'. In the words of yet another pamphlet, Pym appeared to have 'take[n] up an Angel to throw downe the Crowne'. ${ }^{53}$ By the summer of 1643, then, Pym had become for many royalists the malevolent personification of the puritan plot against England's national church.

One springtime tract entitled Pyms juncto summed up these themes from Pym's own perspective. In the broadside, which unequivocally identified him as Charles's chief enemy in Westminster, Pym conversed with his colleagues about their efforts to 'blast the honour of the King' and 'see [his] kingdom down'. Like many other contemporary royalist polemics, the tract reduced the parliamentarian war effort to a collection of rebellious personalities by indicting more than thirty different parliamentary figures by name, from 'holy' Lord Saye and Sele to the 'vain' proto-republicans Henry Marten and Edmund Ludlow. But Pym was the central villain, masterminding the parliamentarians' plan for seeing each 'pin o'th State...undone' and describing himself as 'no lesse then Charles in power and state'. One stark couplet summarized his seditious outlook: 'Charles must not reigne secure, whilst rules a Pym, / The Sun if rise with us, must set with him'. ${ }^{4}$ Here, the entire parliamentarian rebellion was laid squarely at the feet of 'King Pym'.

\footnotetext{
${ }^{49}$ A looking-glasse for rebells, Wing L3024 (Oxford, 1643), sig. A2r.

${ }^{50}$ E.g. Aulicus, no. 12, E.247[26] (Oxford, 25 Mar. 1643), p. 151; ibid., no. 21, E.105[12] (Oxford, 27 May 1643), p. 271.

${ }^{51}$ Ibid., no. 37, E.68[4] (Oxford, 16 Sept. 1643), p. 508; A new diurnall of passages, Wing N631 (Oxford, 1643), sig. A4r. See also John Taylor, The noble cavalier caracterised, Wing T490 (Oxford, 1643), p. 7; The city, 669.f.8[5] (Oxford, 1643).

${ }^{52}$ A letter written out of the country, p. 3.

${ }^{53}$ Gryffith Williams, The discovery of mysteries, E.104[27] (Oxford, 1643), pp. 5-6; [John Taylor], Mercurius infernalis, Wing T482 (Oxford, 1644), pp. 3-4; A new diurnall of passages, sig. A3r.

${ }^{54}$ Pyms juncto, 669.f.8[6] (1643).
} 
As Pym's rebarbative Declaration of March 1643 suggests, these libels left a mark. We have already seen how that tract vociferously disavowed any designs against England's church and state. But in addition to trumpeting Pym's 'care to the Publike Utilie', the Declaration also made a striking observation about the royalists' libellous strategy. Silently acknowledging the 'King Pym' trope, Pym argued that Charles's apologists had purposefully alleged 'that I only have been the man, who hath begot and fostered all the so lamented distractions, which are now rife in this Kingdome' ${ }^{55} \mathrm{He}$ therefore identified the ongoing personalization of English politics as a key element of royalist libellous polemic. Of course, Pym remained tight-lipped about his role in fostering that process among his own partisans by campaigning against Charles's evil counsellors so visibly during the lead-up to civil war. In short, Pym recognized the royalists' libellous tactics precisely because they mirrored his own.

More similarities appear when we take a step back to consider the entire corpus of Pym libels. Much like the increasingly vitriolic parliamentarian polemics against the king's evil counsellors that surfaced during the early 1640s, royalist attacks on Pym generally followed a consistent trajectory from anonymous manuscript squibs to cheap print and eventually into formal royalist productions like Mercurius Aulicus by the time of his death in 1643. This transformation, which paralleled Pym's personal rise to royalist political infamy, illustrates how Charles's partisans consciously drew on earlier scribal material in their early printed polemics. It also captures their efforts to frame the Civil War as a battle of personalities, increasingly by contrasting Pym's singular perfidy with the king's benevolent stewardship. Whether royalists did so intentionally, by following the logic of early Stuart 'politic thinking' to reason that individual plotters were necessarily to blame for England's mounting ills (and thereby avoiding the far more alarming possibility that the entire kingdom had rejected Charles's royal authority), or merely because the notorious personal failings of certain parliamentary leaders made them particularly easy targets, this comprehensive personalization of Civil War politics continued to inform royalist propaganda throughout the remainder of the decade. It also explains the origins of the most vicious Pym libel of the period.

\section{III}

As we have seen, one contemporary slander remained conspicuously absent from Pym's outraged March Declaration: a shocking allegation that Pym was the bestial offspring of a forbidden sexual encounter between his mother and a horse. Like most of the Pym libels, this obscure claim surfaced in numerous scribal and printed royalist texts between 1640 and 1643, culminating with a brief appearance in Aulicus just months before his death. Like the royalists' slanders against Essex and Vane, it was also based in Pym's own family history: in this case, a spurious line in the thirty-year-old will of his long-deceased uncle, William Pym. As Pym's star rose during the early 1640s, royalist scribblers transformed William's unfortunate past into a scabrous slander against

\footnotetext{
${ }^{55}$ Pym, A declaration, pp. 3, 8.
} 
his nephew, complete with allegations of bestiality, miscegenation, and monstrous birth. They did so with purpose, catalysed by the new mid-century politics of personality that Pym himself had helped to pioneer.

The opening four lines of a manuscript poem now held in the Huntington Library capture the libel's essential character. 'There is but one Pim \& noe more', the relevant stanza reads, 'I would he were cut in two / His Sister's an arrant whore / A stone'd horse [i.e. a stallion?] his mother did doe'. ${ }^{56}$ (Another version of this verse, found far afield from London in the personal papers of the Scottish annalist Sir James Balfour, replaces 'stone'd horse' with 'stud horse'.) ${ }^{57}$ Although the poem went on to attack other familiar parliamentarian targets like the cuckolded earl of Essex, this stunning fourth line was by far its most scandalous claim.

Two factors made the horse libel especially transgressive. First, its putative target - Pym's mother, Philippa - had died many years earlier. Speaking ill of the dead was deeply offensive in seventeenth-century England, and contemporaries commented negatively on 'men [who] so delight in sinne' that they would 'rather than be idle from doing evil...take much pains to scandall the Dead' ${ }^{58}$ The second alarming element of the horse libel, unsurprisingly, was the horse itself. Bestiality was a largely taboo subject among early moderns, even if their frequent contact with animals did not render it an especially implausible allegation: the 1655 case of a Staffordshire man named Thomas Cooke, whose son hung himself out of shame after Cooke was merely accused of having 'Buggered a Mare', demonstrates the charge's profound seriousness. ${ }^{59}$ Consequently, even during the early 1640 s, bestiality only rarely featured in libellous polemic. On multiple counts, then, the horse joke represented a particularly vicious slander.

To modern eyes, of course, it also seems patently ridiculous. Remarkably, however, the obscene libel possessed small, if highly tangential, roots in the personal history of John's uncle, William Pym. During the 1580s, William married Agnes Billey, a local woman who apparently carried a flame for another man named Toby Andrewes. After the wedding, to William's chagrin, Agnes initiated (or perhaps openly continued) a long-running sexual relationship with Andrewes while still residing part time with her husband. Thereafter she seems to have 'lived in marriage alternatively with both gentlemen'. William, unsurprisingly, found the arrangement agonizing.

Proof appeared in his 1608 will, which contained a startling final clause directed toward his wayward spouse. The relevant passage described Agnes as one "that I did a longe tyme take for my wife (till of late) shee hath denyed me to be her husband' before listing her infidelities 'which hath happened

\footnotetext{
${ }^{56}$ HEHL, EL 8744a.

${ }^{57}$ National Library of Scotland, Adv.Ms.19.3.8, fos. 38v-39r. I thank Laura Stewart for this reference.

${ }^{58}$ William Sanderson, Aulicus coquinariae, E.1356[2] (1651), sig. A2r. See also Don Herzog, Defaming the dead (New Haven, CT, 2017), pp. 72-87.

${ }^{59}$ Staffordshire Record Office, Q/SR/291, no. 3. See also Courtney Thomas, "Not having God before his eyes": bestiality in early modern England', Seventeenth Century, 26 (2011), pp. 149-73.

${ }^{60}$ Russell, 'Wardship', p. 149.
} 
within these fewe yeres'. The ensuing account was headed by 'Tobye Andrewes the begynner, which I did see with myne owne eyes, when he did more then was fittinge, \& by this...I have lived a miserable lyfe these sixe or seaven yeres.' But William did not end there. 'I give to Agnes', the closing sentence read, 'tenne poundes to buy her a greate horse, for I could not these many yeres please her with one greate enough.' These lines - evidently a crude sex joke - betrayed William's humiliation at his wife's promiscuity. ${ }^{61}$ They also provided the source of the horse libel that would haunt his nephew decades later.

The exact process through which a metaphorical dig at Pym's aunt was transformed into a scandalously literal accusation against his mother between 1608 and 1640 remains unclear. One obvious possibility is the vibrant oral culture of early Stuart England, which facilitated the transmission of many contemporary libels that have otherwise left little trace in modern archives. ${ }^{62}$ Both London and Pym's native Somerset were important hubs for such gossip, and the horse joke would likely have found a welcome home in both arenas. Indeed, ephemeral oral transmission may explain the suggestive line in an early 1620s variant on the well-known 'Parliament Fart' poem that singled out 'Pim' by name during an extended joke on parliamentary 'horses'. ${ }^{63}$ If so, however, we lack any concrete evidence of that process.

Another possible explanation is scribal. Three manuscript copies of the relevant passage remain extant: two in personal manuscript collections and one in the State Papers for the autumn of $1610 .^{64}$ These contemporaries clearly found William's joke compelling. Although the exact provenance of the State Papers copy remains unclear, it includes several interesting clues. First, the unknown transcriber has altered the usual Latin phrase indicating a true copy from 'copia vera' to the more evocative 'copia verissima', perhaps to convey incredulity at the will's contents. Secondly, the back of the transcript is labelled 'lybell \& skandall' in an unknown hand. ${ }^{65}$ This note raises more questions: might Agnes have pursued an action for slander in response to William's angry words, and if so, did the libel's reappearance in a London courtroom accidentally bolster its notoriety? Alternatively, because wills were public documents, it is conceivable that the copies were made later, possibly inspired by oral accounts still circulating in London and/or Somerset. ${ }^{66}$ Absent a positive identification of the hand or a more precise date of transcription, it is difficult to

\footnotetext{
${ }^{61}$ The National Archives, Kew (TNA), PROB 11/16/308. I thank Clive Holmes for a very helpful discussion of William Pym's will.

${ }^{62}$ Adam Fox, Oral and literate culture in England, 1500-1700 (Oxford, 2000); Andy Wood, 'Spectral lordship, popular memory and the boggart of Towneley Hall', in Michael J. Braddick and Phil Withington, eds., Popular culture and political agency in early modern England and Ireland (Woodbridge, 2017), pp. 109-22.

${ }^{63}$ Bod., MS Rawl. Poet. 71, p. 4. See also Michelle O'Callaghan, 'Performing politics: the circulation of the "Parliament Fart", Huntington Library Quarterly, 69 (2006), pp. 121-38.

${ }^{64}$ BL, Harley MS 980; HEHL, EL 703; TNA, SP $14 / 57$, fo. $84 \mathrm{v}$.

${ }^{65} \mathrm{Ibid}$., fo. 84v. The adjacent shorthand reads, loosely, 'extract from will of Wm P'. I thank Christopher Thompson for his help in deciphering this note.

${ }^{66}$ Lloyd Bonfield, Devising, dying and dispute: probate litigation in early modern England (Farnham, 2012).
} 
know for sure. What is certain, however, is that Agnes Pym and her 'great horse' lived on in public memory long after William's demise.

When royalist libellers began consciously framing the parliamentarian rebellion as a seditious design of Pym and his godly cronies, they apparently stumbled upon Agnes's story - possibly after a targeted search inspired by its ephemeral oral presence - and then transformed it into a literal accusation that Pym's mother had slept with a horse and that Pym himself was the bestial offspring. Apart from its indisputable comedic value, the horse joke drew on long-standing early modern connections between sexual and political malignancy to argue that Pym's unhuman ancestry reflected his equally bestial political convictions. This had long been a familiar theme of the 'monstrous birth' narratives that proliferated across early Stuart religious polemic. ${ }^{67}$ It also reflected the burgeoning profile of sexual politics in mid-century royalist satire, which adopted those same tropes to depict the parliamentarian coalition as the misshapen offspring of puritan plotters and the Catholic Whore of Babylon. Consequently, Pym's critics deployed the horse libel to ridicule his personal character while simultaneously making an obscene point about parliamentarian political malignancy writ large.

Several scribal libels invoked the story during the early 1640 s. At least some writers clearly knew the whole narrative, since one poem argued that 'Pim' hoped to be 'greate as his mothers greate horse / Which Wi[lliam] left Agnis though his meaninge was worse'. Remarkably, ten different copies of this verse are still extant in personal commonplace books and poetic miscellanies. ${ }^{68}$ Other libels were more allusive, suggesting that the story had continued to circulate since 1608 and thus required little direct explanation. One unknown poet thus vaguely noted Pym's affinity for a 'gaping horse', while yet another scribbler joked that after 'the horse got Pim...Pim begott a roundhead'. Notably, this latter verse went on to describe Pym as a malignant father of the entire parliamentarian coalition; it, too, remains extant in multiple copies. $^{69}$ Although precise dating is difficult, repeated references to the Five Members in these squibs suggest a composition date of early to mid-1642. Tellingly, nearly every scribal mention of the horse joke was accompanied by libels against other parliamentarians; only rarely did Pym dominate the coverage entirely. Each verse also reflected the imputation of bestiality against Pym's mother and the concurrent claim that Pym himself was the miscegenated result, albeit usually in highly referential language that presumed prior knowledge of the story's basic outlines.

By late 1642, then, William Pym's marital misfortunes had been transformed into a vicious scribal libel at his nephew's expense by enterprising

\footnotetext{
${ }^{67}$ David Cressy, Travesties and transgressions in Tudor and Stuart England: tales of discord and dissension (Oxford, 2000), ch. 2.

${ }^{68}$ BL, Harley MS 2127, fo. 19r. Copies appear in BL, Add. MS 41996 L; BL, Add. MS 78233, fos. 38-40; BL, Harley MS 6918, fo. 36r-v; Bod., MS Ashmole 36-7, fo. 67r; HEHL, EL 8879. The Union first line index (https://firstlines.folger.edu/) lists four more extant copies, but I have been unable to confirm their existence first hand.

${ }^{69}$ HEHL, HM 16522, p. 13; BRBML, Osborn MS b4, fo. 47v. See also Bod., MS Rawl. Poet. 26, fo. $143 \mathrm{v}$.
} 
royalist scribblers anxious to transform the burgeoning Civil War into a contest of personalities between their noble monarch and his debased puritan opposition. Yet notably the horse libel had not yet appeared in print, suggesting that it was possibly still too offensive for truly public dissemination even after the outbreak of war. But with the military conflict heating up, that blanket prohibition was not destined to last for much longer.

Consequently, from early 1643 - roughly coterminous with the royalists' arrival in Oxford-several unofficial loyalist pamphlets referenced Pym's equine ancestry in striking, if still highly allusive, language reminiscent of the earlier scribal efforts. Indeed, at least one was a direct transcription from manuscript. This was The sence of the House, penned by the royalist dramatist Thomas Jordan sometime that year. Circulated in numerous scribal copies as well as a printed Oxford broadside, Jordan's verse briefly referenced the horse joke amid a flurry of attacks on other parliamentary leaders: 'and I quoth [William] Stroud can ly, as fast, / as master Pym can trott', one stanza read. (The tract later dubbed Pym a 'hackney' in another horse-related jibe. $)^{70}$ These lines were no less allusive than the earlier scribal libels, and they remained positively opaque for any readers unfamiliar with William Pym's will. But by shepherding the horse joke into print, even in this obscure form, Jordan propelled it toward much greater polemical relevance.

Soon enough, a more thorough version of the story surfaced in a different royalist pamphlet. Entitled A letter sent by an Oxford scholler, this tract featured a lengthy comedic exchange between a royalist academic and a neutral schoolmaster. After the dialogue appeared two satirical poems. The first, written in Latin, was articulated from Pym's perspective and addressed to an unidentified romantic target, although readers unschooled in the language would be unable to decipher much else. ${ }^{71}$ The second verse, on the other hand - which comprised the lover's reply to Pym's amorous advances - was written in highly accessible English.

Running to well over one hundred lines, the Latin poem (entitled 'Erotic Song - from one of the five Limbs - for his most Beloved girlfriend') took Pym's equine ancestry as its starting point. 'I am the one descended from the darkening Horse', the opening couplet announced, 'my Father...came from the insolent race of horses'. Additional references to the horse joke appeared intermittently, spaced between Pym's erotic musings. 'So, in the same way, was that Horse / Who is said to have loved my mother everywhere', he narrated later, 'so equally my whole heart breathes to Priapus [a Roman god of copulation]'. ${ }^{72}$ Although potent, the equine puns were not the poem's central preoccupation; instead, his pervasive sexual longing took centre stage. Throughout, the poem's overt references to bestiality were tempered only

\footnotetext{
${ }^{70}$ The sence of the House, 669.f.6[117] (Oxford, 1643). For a scribal copy, see BL, Harley MS 1576, fo. 136. See also Lynn Hulse, “"Musick \& poetry, mixed”: Thomas Jordan's manuscript collection', Early Music, 24 (1996), pp. 7-24.

${ }^{71}$ A letter sent by an Oxford scholler, Wing L1589 (164[3?]). Despite the colophon, internal evidence suggests a publication date of early 1643.

${ }^{72}$ Ibid., pp. 13-16. I am deeply grateful to Raashi Rastogi for the translation.
} 
by its learned medium. Masking erotic rhetoric behind a Latin veil had long been an intentional strategy of amorous poets who hoped to restrict their circulation only to sufficiently learned readers; but considering the graphic English descriptions that followed, it was in this case a thoroughly empty gesture.

Like the Latin verses, the lover's English-language response invoked the horse joke within its opening four lines. First, its female narrator questioned Pym's knowledge of Latin, since 'your father horse could teach you none, / Nor was it e're your mother tongue'. More references to Pym's 'foule debauched stuffe' followed. 'Who was your father, you make proofe / By your Coult's tooth, though not your hoofe', read one couplet; 'She that was greate with you, you hold / Did not lye in, but was with fold', exclaimed another. Later in the verse, the lover rebuffed Pym's promise to teach her 'good breeding' and insisted instead that he 'Turne Papist (stallion)', since 'they'le dispense / with whoredome by an Indulgence. ${ }^{73}$ No additional references to Pym's equine attributes appeared in the poem's closing lines, but more vitriol was hardly necessary. Even absent an explicit reference to William Pym's will, the Letter laid out the bestial allegation against Pym and his mother in unprecedented detail.

Several more freelancing royalist pamphlets invoked the horse joke as the military conflict intensified during the summer of $1643 .{ }^{74}$ One, a printed Diurnall purportedly produced in Oxford but likely published on an underground London press, made a lengthy versified allusion that read:

Then Pim like a Pegasus trots up and downe, And takes up an Angel to throw downe the Crowne, He stands like a Centaure and makes a long speech, That came from his mouth, and part from his breech: He move[s] for more horse, that the army may be Part mans flesh and horse flesh as well as he, And hee'l be a Colonell as well as another.

But durst not ride a horse, "cause a horse rid his mother. ${ }^{75}$

Here, the anonymous author linked Pym's legislative proclivities with his mother's bestial dalliance while also imbuing the parliament-man himself with distinctly horse-like qualities.

The Diurnall's language was frank but not entirely forthcoming about the horse joke's origins. Its author conceivably may not have known of William Pym's unfortunate marital history, or s/he may have simply chosen to ignore it to focus more fully on Pym's miscegenated genealogy. Regardless, because William's story was circulating elsewhere in oral and scribal culture, readers possibly knew independently of the drama between Pym's aunt and uncle. But even deprived of that additional context, the Diurnall's pointed attack on

\footnotetext{
${ }^{73}$ Ibid., pp. 17-20.

${ }^{74}$ David R. Como, 'Print, censorship, and ideological escalation in the English Civil War', Journal of British Studies, 51 (2012), pp. 820-57.

${ }^{75}$ A new diurnall of passages, sig. A3r.
} 
his mother provided plenty of libellous vitriol to be enjoyed by sympathetic royalists.

Similar ambiguities shaped other printed references to the horse joke during the year. Abraham Cowley's verse satire The puritan and the papist, which featured numerous attacks on Pym, presented the slur in even vaguer terms: 'onely Pym doth his naturall right enforce', one couplet read, 'by the Mothers side he's Master of the Horse'. (This joke was all the funnier because it played on the royal office of the same name. ${ }^{76}$ Elsewhere, John Taylor's tract A letter sent to London from a spie at Oxford praised Pym for 'understand[ing] more than the Horse which your father did bequeath to your good and spacious mother, for that Horse knew not his own strength, as I hope You do'. ${ }^{77}$ This was yet another spin on William's joke: now the horse was gifted by Pym's father Alexander, although the sexual connotations were rendered clearer here than in Cowley's verse. Still, the allegation remained highly dependent on other iterations of the libel to provide the necessary backstory for Taylor's otherwise opaque jibe.

But, as with the Diurnall, readers did not necessarily need to know William's story to enjoy the joke. Independent of its historical roots, the bestial horseman depicted in these verses represented a potent metaphor for the bastard parliamentarian government now ruling in Westminster. ${ }^{78}$ Cowley's version, in particular, effectively marshalled bestial imagery to present the parliamentman in synecdoche for deeper royalist anxieties about the parliamentary coalition's unnatural usurpation of the king's rightful political authority. Numerous cavalier polemicists invoked this theme during the early 1640s by decrying the parliamentarian 'Monster of Rebellion' in terms that specifically linked monstrosity and pregnancy, including references to 'sunburnt Affrick' and allegations that 'the Divell was its father'. Devoid of its rightful husbandfather the king, these royalists reasoned, parliament could spawn only satanic, monstrous offspring. ${ }^{79}$ Cowley's mocking invocation of Pym's 'natural right' which was, of course, profoundly unnatural - thus reinforced this idea of parliamentarian miscegenation: if the leading parliament-man was only halfhuman, what did that signal about the bestial barbarousness of his followers?

Notably, none of the pamphlets surveyed above were formally approved by the royalist regime, which had largely abstained from forthrightly slanderous polemic in its official productions for much of the year due to Charles's personal aversion toward libellous politics. ${ }^{80}$ But finally, in September 1643,

\footnotetext{
${ }^{76}$ [Abraham Cowley], The puritan and the papist, Wing C6688 (Oxford, 1643), p. 7.

77 [John Taylor], A letter sent to London, Wing T474 ([Oxford], 1643), p. 11.

${ }^{78}$ Mark R. Blackwell, 'Bestial metaphors: John Berkenhead and satiric royalist propaganda of the 1640s and 50s', Modern Language Studies, 29 (1999), pp. 21-48.

${ }^{79}$ [Peter Heylyn], Lord have mercie upon us, E.75[5] (Oxford, 1643), p. 44; The publick faith, 669.f.8[2] (1643); A strange sight to be seen at Westminster, 669.f.8[8] (Oxford, 1643). See also Surekha Davies, Renaissance ethnography and the invention of the human: new worlds, maps and monsters (Cambridge, 2016).

${ }^{80}$ See Thomas Fuller, The church-history of Britain, Wing F2417 (1656), bk 11, p. 208, for a story of Charles refusing to license one anti-parliamentarian libel in late 1643 on the grounds that 'recrimination is no purgation'.
} 
Mercurius Aulicus dubbed Pym 'the son of Agnes' in a clear allusion to the horse joke, signalling that the grandees responsible for regulating Oxford's presses had finally acquiesced to its inclusion in the newsbook's pages. ${ }^{81}$ True, this was an exceedingly mild reference in comparison to the Letter's graphic verses; but its subtlety was telling. To fully understand the aside, a reader needed to know the joke's complete history, including the original victim (Pym's aunt Agnes) as well as the royalist revision that conflated her with his mother Philippa and substituted her fictitious crime for a literal act of bestiality. Aulicus's editors clearly assumed that their audience was familiar enough with the horse joke to require no further explanation. In this sense, the newsbook's throwaway line demonstrates just how thoroughly the horse libel - and, correspondingly, the ongoing personalization of politics that inspired it - had permeated English public culture by the autumn of 1643 .

\section{IV}

Pym's death in December put an end to most, although not all, of the royalists' libellous coverage. For years, hostile writers continued to reference the 'intollerable [parliamentarian] Tyranny' fostered by 'Pym' and his allies, while others described how Pym and his colleagues 'in private exercis'd their Lechery' with the 'Sweet Flesh' of the 'holy Sister[s]. ${ }^{.2}$ More often, they assumed that in death the notorious parliament-man was now 'King[ing] it in the Lower Regions' of hell. One 1645 royalist pamphlet even resurrected the horse libel in a short partisan history of the war: 'Mr Pym was in too, but he was kept close in the Stable, and fed high', it read, 'that he might make no abortive leap, when his time came to appeare. ${ }^{83}$ In general, however, royalists had moved on from Pym by the early months of 1644, as a looming Scottish invasion and Oliver Cromwell's meteoric political ascent presented them with new polemical priorities.

Even after his death, the printed jokes about Pym's equine ancestry remained highly allusive: proof not only of the horse libel's ongoing presence in oral and scribal culture, but also most likely evidence of lingering anxieties about the moral status of public libellous politics. Yet as time wore on, explicit ad hominem attacks grew progressively more common in print, driven forward by personalization of politics first set in motion by Pym and his royalist opponents. Cromwell himself soon assumed Pym's mantle as the arch-villain of royalist polemic, and by 1648 , loyalists were accusing prominent parliament-men like the future regicide Thomas Scot of sexual crimes as grotesque as ravishing and impregnating his young daughter. Parliamentarians participated too: for instance, one later republican apologist even dared to describe how 'King James' had actively participated in Charles I's first sexual experience by 'lay

\footnotetext{
${ }^{81}$ Aulicus, no. 35, E.67[7] (Oxford, 2 Sept. 1643), p. 471.

${ }^{82}$ [John Taylor], The generall complaint of the most oppressed, distressed commons of England, E.300 [15] (Oxford, 1645), p. 2; Ad populum, E.49[2] (Oxford, 1644), p. 3.

${ }^{83}$ Aulicus, no. 6, E.431[20] (2-9 Mar. 1648), sig. Fv; A discourse discovering some mysteries of our new state, E.303[9] (Oxford, 1645), p. 22.
} 
[ing] on that same bed' and 'blowing the bellowes to that fire'. ${ }^{84}$ No publications captured this new libellous milieu more clearly than Henry Neville's Parliament of ladies series, which profiled the obscene sexual antics of literally hundreds of parliamentarian and royalist figures in print for all to read. ${ }^{85}$ By the early 1650s, then, graphic personal libels had become standard fare in midcentury partisan print.

But their printed heyday was short-lived. At the 1660 Stuart Restoration, royalist anxieties about anti-monarchical polemic inspired a crackdown on the kingdom's presses, thereby confining opposition libellers once again to subversive manuscript and oral forms. ${ }^{86}$ Libellous politics would not return to print until the expiration of the Licensing Act in 1679. In the interim, however, the personality-based politics of Civil War polemicists continued to shape late Stuart libel culture despite the new censorship. Whether in royalists' celebratory printed attacks against their defeated puritan enemies - a popular genre that included several recycled versions of the horse joke - or the substantial corpus of scurrilous scribal attacks on Charles II's debauched sexual history, Restoration libellers across the ideological spectrum constructed a slanderous 'iconography' of 'instantly recognizable stock figures' that owed a considerable debt to the libellous caricatures of mid-century polemicists. ${ }^{87}$ In this sense, the defamatory innovations of the early 1640 s left a lasting mark on English libellous politics that transcended even their temporary return to subversive scribal and oral forms after 1660 .

One question remains: why did royalist polemicists obsess over the horse joke? The answer lies in the largely ephemeral oral and scribal culture that sustained the story of William Pym's marital misfortune for decades between the production of his 1608 will and the beginning of English hostilities in 1640. The existence of such a robust narrative tradition made the horse libel an enticing prospect for Charles's partisans, who could presumably count on the joke's longevity to bolster its effectiveness. In fact, this nebulous history ensured that Charles's partisans did not even need to explain the story in full to educated readers; a few well-chosen words ('the son of Agnes') would do.

Of course, neither Pym's mother Philippa nor his aunt Agnes likely ever had sex with a horse. But there was an embarrassing grain of truth to the libel that lent it significant credibility nonetheless: the shameful marital history of William Pym, exacerbated even further by his bizarre decision to commemorate Agnes's infidelity in his will. Given that some of William's contemporaries, when slandered as cuckolds, chose not to take their tormentors to court for

\footnotetext{
${ }^{84}$ Jason McElligott, 'The politics of sexual libel: royalist propaganda in the 1640s', Huntington Library Quarterly, 67 (2004), pp. 75-99, at p. 86; Laura Lunger Knoppers, Constructing Cromwell: ceremony, portrait, and print, 1645-1661 (Cambridge, 2000); [John Hall], The none-such Charles, E.1345[2] (1651), pp. 20-1.

${ }^{85}$ The most spectacular is [Henry Neville], Newes from the New Exchange, E.590[10] (1650).

${ }^{86}$ Edward Legon, Revolution remembered: seditious memories after the British Civil Wars (Manchester, 2019).

${ }^{87}$ Harold Love, English clandestine satire, 1660-1702 (Oxford, 2004), p. 25. For the horse joke after 1660, including two unique verses, see Alexander Brome, Rump, Wing B4851 (1662), pp. 13, 24, 50, 82, 90, 185.
} 
fear of accidentally spreading the story and thereby embarrassing themselves further, William's post-mortem joke must have horrified his kin in its audacity; after all, in doing so, he was effectively outing himself as a failed patriarch. ${ }^{88}$ This humiliating episode subsequently made it difficult for his nephew to engage with the horse joke directly, since by drawing attention to it, Pym risked revealing its embarrassingly true roots. Thus Pym's silence in his 1643 Declaration: there was no clean way to address the story without shooting himself in the foot.

Finally, the horse libel allowed royalist writers to tar Pym with the lurid anti-puritan descriptions of sexual malignancy and bestial monstrosity that were rapidly coming to dominate cavalier polemic by the time of his death in December $1643 .^{89}$ As we have seen, Pym's chaste lifestyle largely prevented royalist libellers from convincingly smearing him as a puritan lecher. The horse joke, while not literally true, therefore gave them one opportunity to undercut Pym's otherwise pristine sexual reputation in memorable fashion while also reinforcing their broader attempts to paint the parliamentarian rebellion as a monstrous uprising against the kingdom's rightful patriarch, Charles I.

For these reasons, the horse libel resonated with royalist polemicists in ways that less grounded or convincing slanders did not. Unfortunately, given the meagre extant evidence, we will probably never know if any contemporaries believed that Pym's mother had in fact slept with a horse. (The surprising capacity of most early moderns for credulousness in the face of the fantastical means that we cannot invalidate the possibility outright.) It seems more probable that the stories about Pym's equine ancestry made some royalist readers chuckle, although this, too, is difficult to ascertain. We are on firmer ground when it comes Pym himself: even if the beleaguered parliament-man's 1643 Declaration did not mention the horse joke directly, it certainly conveyed his frustration at the royalists' endless cheek. But perhaps the most telling reaction came from Pym's parliamentarian allies, who continued to support him despite the slanderous allegations of cavalier polemicists. Indeed, by discounting their enemies' libels on the grounds of partisanship alone, Pym's affiliates trivialized libellous politics in a manner that would have lasting consequences after 1660. Here, in fact, may lie one explanation for the frivolous character of Restoration satire: perhaps, for contemporaries operating within a late seventeenth-century 'culture of libel' in which personal defamation had become an everyday phenomenon, the sheer volume of partisan libels rendered the verity of individual slanders into a moot point. ${ }^{90}$

Such innovations meant nothing to Agnes Pym (or rather "Agnes Andrewes', as she became known once she took up permanently with William's rival Toby after her first husband's death), who passed away

\footnotetext{
${ }^{88}$ Elizabeth A. Foyster, Manhood in early modern England: honour, sex and marriage (London, 1999), p. 86.

${ }^{89}$ On these themes, see Kristen Poole, Radical religion from Shakespeare to Milton: figures of nonconformity in early modern England (Cambridge, 2000).

${ }^{90}$ Love, English clandestine satire, pp. 4-6; Knights, Representation and misrepresentation, p. 223.
} 
sometime around $1635 .{ }^{91}$ But while she did not live to see the havoc that William's will later wreaked on her nephew's reputation, she probably never forgot his crude joke at her expense, which echoed in London courtrooms, personal manuscript collections, and mundane gossip for decades after its first appearance. When royalist polemicists hijacked it for their own purposes during the early 1640s, they did so in service to a budding politics of personality that were rapidly consuming mid-century England's virulent public culture. Thus transformed, libellous politics would continue to dominate English politics into the eighteenth century and beyond. ${ }^{92}$

Acknowledgements. I am grateful to Tom Cogswell, Peter Lake, Noah Millstone, and Talya Sarna, along with the members of the IHR British History in the 17th Century Seminar and the Journal's anonymous reviewers, for their comments on earlier versions of this article.

${ }^{91}$ Russell, 'Wardship', p. 157.

${ }^{92}$ C. R. Kropf, 'Libel and satire', Eighteenth-Century Studies, 8 (1974), pp. 153-68; Ian Higgins, 'Censorship, libel and self-censorship', in Paddy Bullard and James McLaverty, eds., Jonathan Swift and the eighteenth-century book (Cambridge, 2013), pp. 179-98; Marilyn Morris, Sex, money and personal character in eighteenth-century British politics (New Haven, CT, 2014).

Cite this article: Fullerton S (2022). John Pym and Libellous Politics in Early Civil War England. The Historical Journal 65, 591-611. https://doi.org/10.1017/S0018246X21000534 